\title{
The impact of participation within formal standardization on firm performance
}

\author{
Paul Wakke $^{1} \cdot$ Knut Blind ${ }^{1,2,3} \cdot$ Florian Ramel $^{1}$
}

Published online: 6 February 2016

(c) The Author(s) 2016. This article is published with open access at Springerlink.com

\begin{abstract}
Several studies highlight the economic benefits of standards, while the benefit of taking part in standardization remains a rather unexplored mystery to date. In theory, standard setters not only benefit from the possibility to monitor and shape the development of standards but also access a wide range of knowledge sources in the standards committee. Therefore, we investigate how the participation within formal standardization is related to the performance of 1561 German companies. A Cobb-Douglas production function is estimated in order to use the Solow-residuals as indicator for the firm performance. Participation within formal standardization is measured by the number of committee seats at the German Institute for Standardization (DIN). Our results suggest that participation within formal standardization is positively related to firm performance in the manufacturing sector. In the service sector, no clear evidence for such a relationship is found. This finding also holds true when we test if a service providers' intellectual property is well protected through patents.
\end{abstract}

Keywords Participation - Standardization - Firm performance $\cdot$ Cobb-Douglas production function

Knut Blind

knut.blind@tu-berlin.de

1 Chair of Innovation Economics, Technische Universität Berlin, MAR 2-5, Marchstraße 23, 10587 Berlin, Germany

2 Endowed Chair of Standardization, Rotterdam School of Management, Erasmus University, PO Box 1738, 3000 DR Rotterdam, The Netherlands

3 Fraunhofer Institute for Open Communication Systems (FOKUS), Kaiserin-Augusta-Allee 31, 10589 Berlin, Germany
JEL Classification $\quad$ L15 $\cdot$ L25 $\cdot$ C 31

\section{Introduction}

Several studies suggest positive macro- (Blind and Jungmittag 2008; DTI 2005; Cebr 2015; Jungmittag et al. 1999) and microeconomic benefits (for an extensive summary see Swann 2010) of standards in general. Additionally, several scholars explored different benefits of the well-known quality standard ISO 9000 (Briscoe et al. 2005; Corbett et al. 2005; Pekovic and Galia 2009) and the related ISO 14000 standard on environmental management (Tien et al. 2005; Zutshi and Sohal 2004). However, while the economic benefit of standards seems to be widely acknowledged within scientific literature, the benefit of taking part in standardization remains a rather unexplored mystery to date. All the above mentioned studies take the output of the standardization process into account, i.e., the standard (stock). With regard to the standardization process itself, the literature, on the one hand, theoretically addresses possible benefits of the firm's engagement in standardization (Antonelli 1994). On the other hand, motives or driving factors that might foster the firm's propensity to engage in standardization are explored (Blind 2006b; Blind and Mangelsdorf 2016). Consequently, the present paper aims at filling this research gap by theoretically and empirically investigating the impact of participation within standardization on firm performance.

Basically, two different types of standardization exist: de jure and de facto standardization. In the latter case, the standard arises from a standardization struggle (and sometimes from a standard war) between different solutions of different firms or coalitions (Chiesa and Toletti 2003). This paper focuses on de jure standardization that is defined by the existence of independent organizations 
[such as the German Institute for Standardization (DIN) or the International Organization for Standardization (ISO)] and partly by the promulgation of standards by legislative bodies as in the case of mandated standards (David and Greenstein 1990). However, the rather loose tag "de jure standardization" actually fits only in case of mandated standards so that we deem appropriate to use the wording "formal standardization". Formal standardization processes are transparent and open to any company. Accordingly, formal standards are developed in consensus with all interested parties involved as defined within international rules (see, e.g., ISO/IEC Directives). Every organization is invited to join this process, but no organization is obliged to do so. The decision whether to participate in formal standardization or not is exclusively made at organizational level. Thus, organizations that become involved in standardization not only bear the costs for doing so but also derive benefits out of it that apparently exceed the costs.

In theory, standard setters not only benefit from the possibility to monitor and shape the development of standards but also access a wide range of knowledge sources in the standards committee. Consequently, the benefits for the organization are manifold and can influence different profit generating parameters. Standard setters may use standards for the promotion of the diffusion of their innovative products or services so that participation within standardization constitutes a means of marketing. They also may gain competitive advantages by accessing the specifications of upcoming standards prior to their publication and, therewith, prior to competitors not involved in standardization. Besides, we also consider standards committees as a meeting point of different stakeholders (competitors, suppliers, customers, etc.) within a specific scope. The participants of these committees gain access to valuable knowledge that is not necessarily codified in the upcoming standard but shared implicitly. Hence, participation within formal standardization also constitutes a means of knowledge sourcing, which might increase an organization's innovativeness. Chiesa and Toletti (2003) suggest that a single firm quite often is not able to adequately sponsor the adoption of its technology as a standard so that collaborations have to be formed. Consequently, participation within formal standardization is used not only for the diffusion of innovations but also for the generation of knowledge. To sum up, formal standardization might contribute to the performance of its participants in one of the above described manners. Against this background, the paper focuses on firms participating in formal standardization and investigates how this participation contributes to the firm's performance. Methodologically, firm performance is estimated using Solow residuals of a CobbDouglas production function. We consider firm performance to be an appropriate indicator to take all the above mentioned aspects into account simultaneously and holistically.

Within our analysis, two different types of standard setting firms are distinguished, namely manufacturers and service providers. The provision of services is more or less individual, which might cause reluctance concerning standardization. Moreover, several service industries are still highly regulated and only some aspects seem to be worth standardizing. Hence, standardization of services is rather complex compared to that of products (Blind 2006a). The analysis of the service providers' activities within standardization (Wakke et al. 2012) revealed that service providers mainly use standardization for technology-related aspects, while only a minor share of service providers actually set up service standards.

As for the technology-related activities of service providers within standardization, a further distinction can be drawn between service providers that use technologies from the manufacturing industries and service providers that develop technologies themselves by means of research and development activities (Droege and Hildebrand 2009; Miozzo and Soete 2001). Thus, the so-called technologyusing and technology-developing service industries are additionally distinguished in order to shed as much light as possible on the effects of participation within formal standardization on firm performance.

The paper is organized into five sections. The next section briefly reviews the literature on the relation between participation within formal standardization and firm performance, which is the major issue of this analysis to be covered. The third section deals with the methodology, while the fourth section reports the statistics and the results of the empirical analysis. Finally, the fifth section derives implications based on the results.

\section{Theory}

As outlined in the introduction, formal standardization might benefit its participants in different ways. The following paragraphs aim at laying out the theoretical frame of our research. We elaborate three different aspects that might constitute an incentive for companies to join standardization committees instead of behaving as free riders. The three aspects, namely the leverage, the temporal, and the network aspect, can be described as follows.

\subsection{The leverage aspect}

The participants of a standards committee are responsible for specifying standards within the scope of the committee. The technical specifications within the standard are important elements for the successful diffusion of new 
technologies, services, and products not only domestically but also worldwide (Blind 2006b). At firm level, standards can be used to increase or defend market power (Lecraw 1984) by minimizing the technical distance between the standard itself and the present technical specifications of each firm's current product and processes (Antonelli 1994, p. 200). More precisely, participants may adjust the content of the standard to their benefit in order to gain a competitive advantage (Fernández et al. 2000, p. 89), to prevent competitors from gaining advantages at their expense (Weiss and Sirbu 1990) or to disadvantage rivals by raising their costs (Salop and Scheffman 1983, 1987). This perspective is in line with the partially excludable characteristic of standards, meaning that outsiders of the standards committees might face considerable disadvantages when adhering to a standard (Antonelli 1994, p. 200).

The costs of adopting a given standard (switching costs) and the costs for participating in formal standardization (sponsoring costs) interact with each other. In this paper, a negative relation between the switching costs and sponsoring costs is assumed, i.e., the more effort is put into standardization, the less effort is needed to comply with the requirements of the standard later on. Accordingly, participation within standardization lowers switching costs.

Furthermore, the demand for standardized products may be higher due to network externalities, lower transaction costs, and enhanced diffusion rates (Antonelli 1994, p. 201). Blind (2006b, p. 161) argues that "participation in standardization is certainly a strategy to shape foreign markets according to specifications of the own products or technologies". Thus, manufacturers and service providers might leverage the standardization process to boost sales (Blind 2002). Simultaneously, owners of intellectual property rights (IPRs) might leverage the standardization process to increase the firm's royalties (Berger et al. 2012; Hytönen et al. 2012). The demand increasing effect is all the more important, the more novel the product or service is. Standards help to overcome uncertainties embodied in innovative technologies and therewith reduce adoption lags of new products or services (Antonelli 1994, p. 201). In conclusion, we assume that participation within standardization raises the firm's performance by reducing switching costs and/or increasing demand in one of the ways described above.

\subsection{The temporal aspect}

According to Blind (2006b, p. 159), the temporal aspect can be elucidated in a way that "participants in the standardization process may have advantages compared with outsiders, due to their early involvement in the development of the standard". Simultaneously, the standard setters can be regarded as owners of a club good (i.e., the specifications within the standard) until the standard is published (Antonelli 1994). Consequently, standard setters might benefit from this temporary club good by adapting the production process or the service provision to the requirements of the upcoming standard before publication. In this regard, the lead time differs and depends mainly on the time it takes until all participants approve the final standard for publication in consensus. A recent study by Simcoe (2012) shows that the lead time increases the greater the commercial interests of the committee members are. Rent seeking is found to be a major reason for prolonged negotiations. Accordingly, the temporal aspect might be decisive for "creating early knowledge" (Hytönen et al. 2012, p. 2) so that participation within standardization might increase the performance of its participants at least for a restricted time. Depending on the delay of adoption by outsiders, performance may also increase for a longer period.

\subsection{The network aspect}

Whereas both the leverage and the temporal aspect only come into effect after publication of the standard, the network aspect explicitly deals with the benefits resulting from participating within a standardization committee. Participation within standardization can be regarded as interorganizational cooperation. According to the relational view (Dyer and Singh 1998), cooperating firms may realize "interorganizational competitive advantages" based on a joint combination of resources in unique ways. Many scholars have extended the "standard Schumpeterian analysis" (Love and Roper 1999, p. 43) and emphasize the role of networks, communities, and linkages as alternative to internal R\&D efforts (Chesbrough 2003; Fernández et al. 2000; von Hippel 1988). More detailed, von Hippel (1988) proves that a firm's customers and suppliers are its main source of innovative ideas. Fernández et al. (2000) highlight the importance of collaborations to continuously update different kinds of intangible assets like the technological capital. Laursen and Salter (2006) evidence the contribution of openness to innovation performance among British manufacturing firms. Quite similarly, Leiponen and Helfat (2010) conclude that Finnish manufacturing firms may improve their odds of successful innovation by accessing a large number of knowledge sources alongside pursuing multiple parallel objectives. Belderbos et al. (2004) analyze the impact of different types of R\&D cooperation on firm performance differentiating between four R\&D partners (competitors, suppliers, customers, and universities). Basically, competitor and supplier cooperation increases productivity due to incremental innovations, while customer and university cooperation is an important knowledge source for firms pursuing radical innovations. 
According to Duysters and Lokshin (2011), however, the positive effect of openness towards innovativeness seems to be limited. Among Dutch companies, they proved the existence of such a firm specific limit, above which the marginal costs of managing the portfolio complexity exceeds the expected benefits.

Although there is an inverse U-shape relation between openness of a company and its innovative performance, it seems obvious that participants within standardization might increase their (innovative) performance due to knowledge creation and exchange with competitors, suppliers, customers, and other stakeholders in the standards committees (Blind 2006b, p. 159). In doing so, participants access not only explicit knowledge that is formulated in the standard. They also access tacit knowledge, i.e. the leakage which cannot be controlled for in the standards committee. Thus, participation in standardization might raise the innovativeness and therewith increase firm performance.

Hypotheses Based on these theoretical considerations, a positive relation between the participation in formal standardization and firm performance is hypothesized (Hypothesis 1).

However, we expect Hypothesis 1 to be only conditionally applicable for the technology-developing service providers. As briefly mentioned in Sect. 1, service providers mainly focus on technology-related aspects within standardization, not on the standardization of services (Wakke et al. 2012). These service providers focusing on technologies either use technologies from manufacturers in order to support their service provision or develop technologies on their own by means of research and development. The latter come from the fields of information technology-related services, architectural and engineering activities or scientific research and development (Vence and Trigo 2009; Hipp and Grupp 2005, p. 523). With respect to these technology-developing service providers, some of the theoretical aspects outlined above might not be valid. These service providers might face difficulties to benefit from the leverage aspect and the temporal aspect.

From a market perspective, technology-developing service providers do not use the technology by themselves. They contribute to technology development but have negligible product sales (Hytönen et al. 2012). Accordingly, they are reliant on selling the technology to manufacturers or technology-using service providers. Hence, only if the technology is effectively protected by intellectual property rights (IPR), the technology-developing service providers are able to realize profits from standard setting by enhancing the visibility and diffusion of their technologies. This way, they are able to generate license revenues or similar incomes as shown by Pohlmann et al. (2015). This assumption regarding the importance of IPR protection and its benefits is in line with findings by Rysman and Simcoe (2008). They show that patents are cited more often as soon as they are disclosed to a standard setting organization in order to be used in a standard.

Consequently, it is hypothesized that participation within standardization of technology-developing service providers is positively related to firm performance conditional upon the adequate protection of the firm's intellectual property (Hypothesis 2).

\section{Methodology}

A multiple-step regression analysis is used to empirically investigate the hypothesized relations. In the first step, the firm performance is estimated. The further steps explore the relation between different factors (such as the engagement in standardization) and the estimated firm performance. As for the first step, the Solowresiduals of a Cobb-Douglas production function are used as proxy for the firm performance as done by van de Wiele (2010). Olley and Pakes (1996) give another example for the use of an unobserved residual as a measure of productivity.

The microeconomic production function [see Eq. (1)] uses two company-specific input factors, the number of employees $\left(L_{i}\right)$ and the capital stock $\left(C_{i}\right)$. The profit or value added $\left(Y_{i}\right)$ serves as the output measure. The estimated coefficients are normally taken as elasticity of the respective input factor.

$\ln Y_{i}=\alpha_{1}+\beta_{1} \ln L_{i}+\beta_{2} \ln C_{i}+\varepsilon_{i}$

However, we are not interested in the coefficients but in the estimated error terms $\left(\varepsilon_{i}\right)$. The error term of a regression model aims at capturing all factors influencing the dependent variable other than the regressors. More precisely, the firm-specific error term (i.e., residual) constitutes an appropriate performance indicator for all factors other than the labor and capital stock (e.g., the firm's innovativeness or the firm's engagement in formal standardization). Accordingly, the error term of Eq. (1) is used as proxy for the firm performance $\left(P E R F_{i}\right)$.

Although the model in Eq. (1) has been called somewhat "skeletal" (Griliches 1995, p. 55), we consider it as a good instrument for our purposes. Determining the correct measures for $L$ and $C$ has been proven to be difficult. Especially when calculating the capital input, it is not always clear which factors to include and how to weigh them (Griliches 1995). In our study, however, we do not treat the participation in standardization as capital input (i.e. as a kind of R\&D expense). Therefore, it is convenient for us to use this simple model as a baseline in order to be able to concentrate on the error term as a measure for 
factors that cannot be attributed to $L$ or $C$. Regarding the results, it is important to keep in mind that other factors than participation in standardization are also subsumed in the Solow residual. This is why a strong theoretical background with clear assumptions is needed to explain the outcomes (Morrison 1999).

The second stage of our regression model is a separate step. The microeconomic production function of Eq. (1) was merely a starting point to extract the residual. The second step addresses those different factors that might be related to the firm performance $\left(P E R F_{i}\right)$ and have not been captured by $L$ or $C$. In order to determine these factors, the hypothesized positive relation between the participation in standardization and firm performance is tested. To explain as much variety of the firm performance as possible, additional factors are considered as well. We carry out the following steps to conduct our analysis. First, the effect of the innovativeness on firm performance is addressed. Going back to the early work of Schumpeter (1934), innovation has been recognized as a key element of competition. Innovative companies gain market shares from non-innovators. Consequently, scholars evidenced a positive effect of innovation (Crépon et al. 1998) or corporate R\&D (Kumbhakar et al. 2012) on performance or productivity. However, meanwhile this one-way causality seems to turn into a "self-reinforcing virtuous circle between innovation and economic performance at firm level" (Cainelli et al. 2006, p. 454). A similar result is found by Koellinger (2008), who analyzes 7302 European enterprises and comes to the result that service as well as product innovation is positively associated with profitability, although the direction of the causality is ambiguous. Artz et al. (2010) evidence a positive relation between product announcements and two measures for the firm performance, return on assets and sales growth. An unexpected negative relationship between patents and firm performance is revealed as well. However, they argue that this result stems from an increased strategic patenting at firm level. Nevertheless, the possible effects of the firm's innovativeness on firm performance are addressed within our second stage regression. The patent stock of each firm is used as proxy for the innovativeness. In addition, the patent stock is used for measuring the protection of intellectual properties in order to test our second hypothesis.

Second, the size of a company might influence its performance. According to Tsai (2005), both large and small firms have higher competitive advantages with respect to the R\&D productivity than middle sized companies. Dhawan (2001) first gives a short overview of the literature regarding the relationship between firm size and profit rate which slightly tends towards a decline with firm size before empirical evidence is found that larger US firms are less productive than their smaller counterparts. Irrespective of the different results, firm size might affect firm performance. Accordingly, the second stage allows for this possible effect. We anticipate a U-shaped relationship that is estimated by the inclusion of a squared term of the size variable, which is expressed by the number of employees. ${ }^{1}$

Third, we consider export as another factor that is probably related to the performance of a firm. As in the case of innovative companies, the available literature in this field considers a bidirectional relationship between export activities and firm performance. In this regard, two different patterns, "self-selection" and "learningby-exporting", are under investigation (Kneller and Pisu 2010; Manez-Castillejo et al. 2010). The former pattern deals with the self-selection of companies into export markets, i.e., only the ex-ante more efficient companies enter foreign markets. The latter pattern addresses the effect of export on productivity, i.e., exporters are more productive than non-exporters. Kneller and Pisu (2010) evidence the effect of export on productivity among UK firms across a wide range of performance indicators (sales growth, profitability growth as well as several innovation indicators). Following this line of argumentation, the effect of exporting activities on firm performance is tested.

Fourth, we control for firm performance in the past in order to capture other unobserved factors like management skills for which we have no data.

Finally, we control for differences between the more or less heterogeneous industries alongside the differentiation between the manufacturing and the service industries in general. Considering all of the above mentioned control variables, we end up with the following model [Eq. (2)] for a nonlinear relationship between company size and firm performance:

$$
\begin{aligned}
\text { PERF }_{i}= & \alpha+\beta_{1} P A R T_{i}+\beta_{2} I N N O_{i}+\beta_{3} S_{I Z E_{i}} \\
& +\beta_{4}\left(S_{Z} I Z E_{i}\right)^{2}+\beta_{5} E X P_{i}+\beta_{6} P A S T_{i}+\beta_{7} X_{i}+\varepsilon_{i}
\end{aligned}
$$

with $P E R F=$ the firm performance estimated by Eq. (1), $P A R T=$ the participation level in formal standardization, $I N N O=$ the innovativeness of the firm, SIZE = the size of the firm, $E X P=$ the export activity of the firm, $P A S T=$ past firm performance, $X=$ a vector of industry dummies based on the two-digit NACE code.

In order to explicitly test the effect of the right hand side (RHS) variables of Eq. (2) on the firm performance that is estimated for the year 2009, we use appropriate time-lags for the independent variables. More details in this regard will be provided in the statistics section.

\footnotetext{
1 A linear relationship was also tested but performed less well. This holds true for all nonlinear model specifications we use.
} 
However, the literature on factors that influence the companies' decision to join standardization (Blind 2006b; Wakke et al. 2015) heavily suggests interactions between the participation level PART and the other RHS variables in Eq. (2). When estimating a multiple regression model with correlation among the RHS variables, also called multicollinearity, the overall explanatory power of the model is not compromised. The individual coefficient estimates may not be correct, however. Moreover, these reciprocal dependencies may lead to endogeneity due to a simultaneity bias. Consequently, these issues are taken into account by performing a multiple-step procedure as similarly suggested by Crépon et al. (1998). We conduct one more step before estimating Eq. (2). In this intermediate step we regress the participation level PART on all the remaining RHS variables as shown in Eq. (3).

We again allow for a non-linear relationship between the innovativeness and the participation level as proved by Blind (2006b) at company level and Blind (2002) at industry level. For reasons of unintended knowledge spillovers especially to competitors, highly innovative companies or industries might stay away from standardization.

$$
\begin{aligned}
\text { PART }_{i}= & \alpha+\beta_{1} I N N O_{i}+\beta_{2}\left(I N N O_{i}\right)^{2}+\beta_{3} \text { SIZE }_{i} \\
& +\beta_{4} E X P_{i}+\beta_{5} P A S T_{i}+\beta_{6} X_{i}+\varepsilon_{i}
\end{aligned}
$$

Once again, we use the estimated error terms $\left(\varepsilon_{i}\right)$, i.e., in this case the participation level of a company independent of its innovativeness, size, export activities, and industry specific peculiarities. The new variable [the error term of Eq. (3)] is called participation intensity $\left(P A I N_{i}\right)$. Equation (2) is adjusted $\left(P A R T_{i}\right.$ is replaced by $\left.P A I N_{i}\right)$, which leads us to the following equation:

$$
\begin{aligned}
\text { PERF }_{i}= & \alpha+\beta_{1} \text { PAIN }_{i}+\beta_{2} I N N O_{i}+\beta_{3} \text { SIZE }_{i} \\
& +\beta_{4}\left(S I Z E_{i}\right)^{2}+\beta_{5} E X P_{i}+\beta_{6} P A S T_{i}+\beta_{7} X_{i}+\varepsilon_{i}
\end{aligned}
$$

as mentioned in the introduction, the two most prominent types of service providers are distinguished within the model dealing explicitly with the service industries: technologyusers and technology-developers. In order to test the hypothesized differences (Hypothesis 1 for the technology-using and Hypothesis 2 for the technology-developing service providers), a dummy variable $\left(\mathrm{TECH}_{i}\right)$ that identifies the technology-developing service providers is set up. This dummy and an interaction term of this dummy with the participation intensity $\left(P A I N_{i}\right)$ are included in Eq. (4). Moreover, an interaction between the dummy variable $\left(T E C H_{i}\right)$, the participation intensity $\left(P A I N_{i}\right)$, and the innovativeness $\left(I N N O_{i}\right)$ allows for testing our second hypothesis. Integrating these three factors into Eq. (4) leads us to the following regression model for studying peculiarities within the service industry:

$$
\begin{aligned}
\text { PERF }_{i}= & \alpha+\beta_{1} \text { PAIN }_{i}+\beta_{2}\left(\text { PAIN }_{i} \times \text { TECH }_{i}\right) \\
& +\beta_{3}\left(\text { PAIN }_{i} \times \text { TECH }_{i} \times I N N O_{i}\right)+\beta_{4} \text { TECH }_{i} \\
& +\beta_{5} I N N O_{i}+\beta_{6} \text { SIZE }_{i}+\beta_{7}\left(\text { SIZE }_{i}\right)^{2}+\beta_{8} E X P_{i} \\
& +\beta_{9} \text { PAST }_{i}+\beta_{10} X_{i}+\varepsilon_{i}
\end{aligned}
$$

using the methodology described above, we end up with three steps. First, the firm performance $\left(P E R F_{i}\right)$ is estimated by applying Eq. (1) to the data. Second, the participation intensity $\left(P A I N_{i}\right)$ is estimated by applying Eq. (3). Third, Eqs. (4) and (5) are estimated using the estimates of the first and second step.

Alongside this parametric approach, in which we perform several OLS-regression analyses, the non-parametric bootstrap method is used. This approach checks the reliability of our results by checking the validity of our point estimates. Bootstrapping means constructing a sampling distribution based on random sampling with replacement from the original data instead of making distributional assumptions for hypothesis testing as in the case of parametric statistics (Friedman and Friedman 1995). This is necessary because econometrically the underlying distribution, i.e. the real production frontier, of our third step equations is not clear. Thus it is not clear if the results are merely random outcomes originating from the underlying data. A similar bootstrapping procedure has, e.g., been developed by Simar and Wilson (1999). They use bootstrapping to validate the estimates of Malmquist indices, which also suffer from the lack of a known underlying distribution function. Consequently, the data is resampled and the resamples or pseudo-samples are used to perform the above described methodology in order to validate the coefficients estimates. The number of resamples is chosen to be big enough to produce reliable results on significance levels of up to 0.001 . The system bootstrapping with 19,999 replications leads to 19,999 estimates for the effect of the participation intensity $\left(P A I N_{i}\right)$ on firm performance, i.e., 19,999 values for the respective coefficient $\beta_{1}$ of Eq. (4) and for the coefficients $\beta_{1}, \beta_{2}$ and $\beta_{3}$ of Eq. (5). Additionally, the coefficient of the INNO variable as well as the coefficients of several interaction terms to be introduced later are bootstrapped. In a final step, the sampling distribution of the coefficients is described in order to derive conclusions with regard to our hypotheses. The following section describes our sample and applies the methodology to the data.

\section{Statistics and results}

Our sample is based on the Hoppenstedt database, which provides basic information of German companies. Prior to applying our methodology, the sample is corrected for 
outliers by excluding observations \pm 4.0 standard deviations (SD) away from the mean for each of the variables as suggested by Cohen et al. (2003). Even though the Hoppenstedt database provides access to more than 300,000 company profiles, only for 1561 of these companies all variables required for our analysis are available. The sample consists of 823 service providers and 738 manufacturers. The decision whether a company is assigned to the service industries or manufacturing industries is made by considering all NACE (Statistical Classification of Economic Activities in the European Community) classifications provided by the Hoppenstedt database.

In order to make the distinction of the main NACE classification more accurate, two further conditions are imposed for the purpose of detecting service providers. The main NACE classification and the majority of all subordinated NACE classifications of each organization have to be within the NACE divisions above 44 to be assigned to the service industries. Table 1 provides the industrial structure of the sample following the NACE classification. Moreover, to give and idea of the structure of the German economy, the gross value added by each sector in 2008 and its share in the total gross value added were included.
Roughly one third of the total value added is created by the industry sector, the primary sector accounts for only one percent. The biggest part of two thirds is to be attributed to the service sector. Our sample matches roughly the overall sector composition in Germany. "Manufacturing", "wholesale and retail trade; repair of motor vehicles and motorcycles", and "financial and insurance activities" are somewhat overrepresented while "real estate activities" is underrepresented. This will, however, not have any negative impact on our findings as they concern firm level without trying to make a statement about the economy as a whole. Hence, it is of greatest importance to use as many observations as possibly available. Using a random sample will also help us to avoid a sample selection bias in our model regarding the variables participation in standardization and for the measure of innovativeness. Our sample both includes companies that hold seats in participation committees and that do patent as well as companies, which do not engage in those activities (Crépon et al. 1998; Hall et al. 2009).

The level of participation in standardization is measured by the number of committee seats that every company held at DIN in early 2010. Unfortunately, no earlier data was

Table 1 Industrial structure of the sample

\begin{tabular}{|c|c|c|c|c|}
\hline Industry & $\begin{array}{l}\text { Number of } \\
\text { observations }\end{array}$ & $\begin{array}{l}\text { Percentage } \\
(\%)\end{array}$ & $\begin{array}{l}\text { Gross value added ( } 2008 \text {, } \\
\text { billion Euro) }\end{array}$ & $\begin{array}{l}\text { Percentage } \\
(\%)\end{array}$ \\
\hline Manufacturing & 500 & 32.0 & 492,100 & 22.20 \\
\hline $\begin{array}{l}\text { Wholesale and retail trade; repair of motor vehicles and } \\
\text { motorcycles }\end{array}$ & 243 & 15.6 & 220,910 & 9.96 \\
\hline Financial and insurance activities & 120 & 7.7 & 83,640 & 3.77 \\
\hline Professional, scientific and technical activities & 114 & 7.3 & 147,430 & 6.65 \\
\hline Human health and social work activities & 111 & 7.1 & 150,680 & 6.80 \\
\hline Construction & 97 & 6.2 & 93,320 & 4.21 \\
\hline Information and communication & 70 & 4.5 & 87,260 & 3.94 \\
\hline Transporting and storage & 65 & 4.2 & 95,960 & 4.33 \\
\hline Electricity, gas, steam and air conditioning supply & 60 & 3.8 & 51,940 & 2.34 \\
\hline Real estate activities & 56 & 3.6 & 266,450 & 12.02 \\
\hline Administrative and support service activities & 42 & 2.7 & 110,730 & 4.99 \\
\hline $\begin{array}{l}\text { Water supply; sewerage; waste management and } \\
\text { remediation activities }\end{array}$ & 25 & 1.6 & 24,160 & 1.09 \\
\hline Other service activities & 12 & 0.8 & 61,750 & 2.79 \\
\hline Accommodation and food service activities & 11 & 0.7 & 35,610 & 1.61 \\
\hline $\begin{array}{l}\text { Public administration and defense; compulsory social } \\
\text { security }\end{array}$ & 10 & 0.6 & 132,080 & 5.96 \\
\hline Education & 9 & 0.6 & 96,590 & 4.36 \\
\hline Arts, entertainment and recreation & 8 & 0.5 & 31,940 & 1.44 \\
\hline Mining and quarrying & 7 & 0.4 & 6570 & 0.30 \\
\hline Agriculture, forestry and fishing & 1 & 0.1 & 21,190 & 0.96 \\
\hline
\end{tabular}

Source for value added: German Federal Statistical Office. Does not add up to $100 \%$ because gross value added by private households was left out 
accessible. Only full expert status, i.e., no temporary engagement (e.g., visitor status), is considered. It can, therefore, be assumed that all companies have participated in standardization for at least one year, which is supported by the low level of fluctuation found by comparing most recent data of involvement in 2011 with the data from 2010.

Innovativeness is measured by the stock of national, European and international patents calculated from 2000 to 2008 by the perpetual inventory method with a constant depreciation rate (15 percent) as being well described by Czarnitzki and Kraft (2010). The matching of the patent stock to the firms is achieved by comparison of company names and addresses. Certainly, this rather technical innovation indicator does not fully capture the various forms of innovation in the service industries and scholars have meanwhile developed more appropriate indicators in this regard (Schmoch and Gauch 2009; Gotsch and Hipp 2012). However, service providers use standardization mainly for technology-related innovation activities (Wakke et al. 2012) so that we regard patents as an appropriate indicator for innovation within our sample. The dummy variable that differentiates between technology-developing and technology-using service providers is built based on the main NACE classification. Service providers primarily classified within NACE 2.0 division 62, 63, 71 or 72 were assigned to the technology-developing service providers. This approach is based on the literature (Glueckler and Hammer 2011; Hipp and Grupp 2005, p. 523; Vence and Trigo 2009). Table 2 provides a summary of all variables including a short description, the measurement, and the source.
Table 3 provides the descriptive statistics for all variables that entered the analysis. With regard to the entire Hoppenstedt database (see last column in Table 3), our sample is slightly skewed towards the larger companies caused by the restricted data availability of the smaller companies. However, the regression model controls for the company size so that this possible bias is taken into account. Based on the tendency towards larger companies in our dataset, one might expect that standardization $\left(P A R T_{i}\right)$ and innovation activities $\left(I N N O_{i}\right)$ (that are not gathered through Hoppenstedt) are above average and therewith do not adequately represent the population of German companies. Yet the average number of committee seats of the standard setters in our dataset (2.1 seats) is below the average number of seats held by German standard setting companies (3.7 seats). Moreover, the average patent stock of the patent holders in our sample (5.0 patents) is below the average patent stock of German patent holding companies (31.2 patents).

Table 4 presents the estimation results of the CobbDouglas production function [Eq. (1)]. It is noteworthy that the coefficients for $\operatorname{Ln} L$ and $\operatorname{Ln} C$ do not add up to 1 . This indicates that, as expected, Eq. (1) cannot serve as a proper indicator for firm performance on its own. As we concentrate on the use of the residuals of these estimations, the results are still usable for our purposes.

A potential omitted-variable bias is being accounted for further below. The error terms of the two models are used to build the new variable firm performance $\left(P E R F_{i}\right)$ as described in Sect. 3. Figure 1 plots the histogram of the firm performance $\left(P E R F_{i}\right)$, i.e., the (Solow) residuals of Eq. (1).

Table 2 Variables

\begin{tabular}{llll}
\hline Variable & Description & Measure & Source \\
\hline Y & Profit & Profit realized in 2009 (million Euro) & Hoppenstedt database \\
$\mathrm{L}$ & Number of employees & Number of employees in 2009 & Hoppenstedt database \\
$\mathrm{C}$ & Capital stock & Nominal capital (million Euro) & Hoppenstedt database \\
PART & Participation level & Number of committee seats within the German Institute for & DIN German Institute for \\
& & Standardization & Standardization \\
INNO & Innovativeness & Patent stock in 2000-2008 divided by the number of employees & PATSTAT database \\
SIZE & Number of employees & Natural logarithm of the number of employees in 2008 & Hoppenstedt database \\
EXP & Export & 1 if the company sells products outside Germany; 0 otherwise & Hoppenstedt database \\
PAST & Past firm performance & Profit realized in 2008 (million Euro) divided by the number of & Hoppenstedt database \\
& & employees in 2008 & Own calculation \\
PAIN & Participation intensity & Error term of Eq. (3) & Own calculation \\
PERF & Firm performance & Error term of Eq. (1) & 1 if service provider is classified within NACE 2.0 division 62, 63, Hoppenstedt database \\
TECH & Technology-developing & 71 or 72; 0 otherwise & \\
& service providers & &
\end{tabular}


Table 3 Descriptive statistics

\begin{tabular}{|c|c|c|c|c|c|c|}
\hline & \multicolumn{2}{|c|}{ Service providers $(\mathrm{N}=823)$} & \multicolumn{2}{|c|}{ Manufacturers $(\mathrm{N}=738)$} & \multicolumn{2}{|c|}{ Hoppenstedt } \\
\hline & Mean & SD & Mean & SD & Mean & SD \\
\hline Ln Y & -0.454 & 2.123 & -0.154 & 1.845 & -0.131 & 1.931 \\
\hline $\mathrm{Ln} \mathrm{L}$ & -4.599 & 1.737 & -4.549 & 1.232 & -2.995 & 1.338 \\
\hline Ln C & -0.019 & 2.618 & -0.016 & 2.009 & -2.519 & 1.692 \\
\hline PART & -0.063 & 0.501 & -0.176 & 0.660 & - & - \\
\hline INNO & -0.008 & 0.185 & -0.009 & 0.069 & - & - \\
\hline SIZE & -4.574 & 1.734 & -4.553 & 1.225 & -3.002 & 1.341 \\
\hline EXP & -0.074 & 0.262 & -0.293 & 0.455 & -0.065 & 0.246 \\
\hline TECH & -0.094 & 0.291 & - & - & - & - \\
\hline
\end{tabular}

Table 4 Estimation of the Cobb-Douglas production function [Eq. (1)]

\begin{tabular}{lll}
\hline $\mathrm{Y}=\ln \mathrm{Y}$ & $\begin{array}{l}\text { Service provider } \\
-(1)\end{array}$ & $\begin{array}{l}\text { Manufacturer } \\
(2)\end{array}$ \\
\hline Ln L & $-0.295^{* * *}$ & $-0.272^{* * *}$ \\
& $(7.75)$ & $(5.44)$ \\
Ln C & $-0.318^{* * *}$ & $-0.376^{* * *}$ \\
& $(12.60)$ & $(12.28)$ \\
Constant & $-1.817^{* * *}$ & $-1.386^{* * *}$ \\
& $(-9.76)$ & $(-5.90)$ \\
$\mathrm{R}^{2}$ & $26.5 \%$ & $24.0 \%$ \\
Obs. & 823 & 738 \\
\hline
\end{tabular}

The asterisks represent the levels of significance: $* * *<0.001$, $* *<0.01, *<0.05$ and ${ }^{\dagger}<0.1$. T-values in parentheses

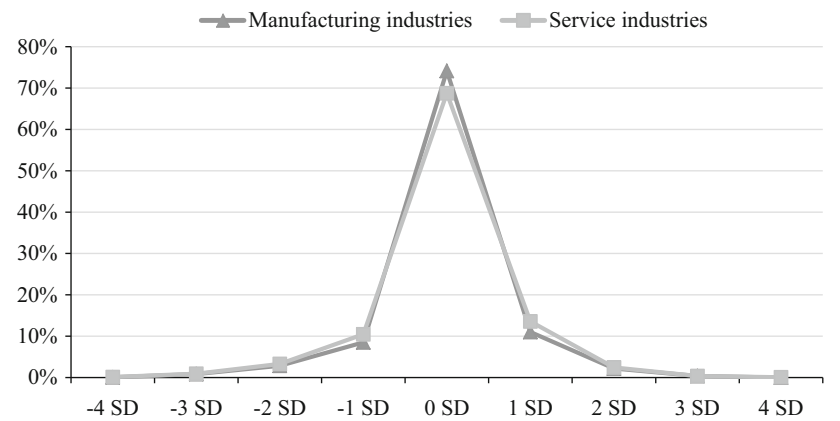

Fig. 1 Histogram of the Solow residuals in terms of the standard deviation (SD)

In the second step, the standardization intensity $\left(P A I N_{i}\right)$ is estimated by applying Eq. (3) to the data (see Table 5). Finally, these results are used to estimate the effects of all the independent variables on the firm performance as described by Eqs. (4) and (5). Table 6 provides the results that we are eventually interested in.

Our basic model specification is reported in columns (1) and (2) of Table 6. The regression results support Hypothesis 1 for manufacturers and within the aggregated model. The participation intensity $\left(P A I N_{i}\right)$ is able to
Table 5 Estimation of Eq. (3) (Step 2)

\begin{tabular}{lll}
\hline Y = PART & $\begin{array}{l}\text { Service provider } \\
(1)\end{array}$ & $\begin{array}{l}\text { Manufacturer } \\
(2)\end{array}$ \\
\hline SIZE & $0.16^{* * *}$ & $0.18^{* * *}$ \\
& $(0.58)$ & $(4.60)$ \\
INNO & 0.58 & $0.42 * * *$ \\
& $(1.32)$ & $(3.97)$ \\
$(\mathrm{INNO})^{2}$ & -0.59 & $-0.38 * * *$ \\
& $(-1.36)$ & $(-3.52)$ \\
EXP & -0.03 & $0.07 \dagger$ \\
& $(-0.77)$ & $(1.87)$ \\
PAST & -0.02 & 0.03 \\
& $(-0.50)$ & $(0.83)$ \\
$\mathrm{R}^{2}$ & $10.6 \%$ & $14.9 \%$ \\
Obs. & 823 & 738 \\
\hline
\end{tabular}

The asterisks represent the levels of significance: $* * *<0.001$, $* *<0.01, *<0.05$ and ${ }^{\dagger}<0.1$. T-values in parentheses. All regression models include 42 service industry dummies which are not reported here; reference industry (omitted category): NACE 2.0 division 46 "Wholesale trade, except of motor vehicles and motorcycles"

significantly and positively explain the firm performance, which confirms the hypothesized positive relationship between participation in standardization and firm performance. Participation in formal standardization is able to explain up to one percent of the firm performance. For the service industries, no significant positive relation between participation intensity and firm performance is estimated.

Alongside the parametric regression analyses, the dataset is bootstrapped as described above. This additional step aims at reducing a possible bias caused by the fact that the dependent variable $\left(P E R F_{i}\right)$ is not observed but estimated, which might harm inference. Therefore, a sampling distribution of the coefficients of the PAIN and INNO variables of Eqs. (4) and (5) as well as of the two coefficients of interest of the interaction terms in Eq. (5) is drawn. The lower rows of the table report the characteristic features 
Table 6 Estimations of Eqs. (4) and (5) (Step 3)

\begin{tabular}{|c|c|c|c|}
\hline \multirow[t]{2}{*}{$\mathrm{Y}=\mathrm{PERF}$} & \multicolumn{2}{|l|}{ Equations (4) } & \multirow{2}{*}{$\begin{array}{l}\text { Equations (4) } \\
\text { Service provider } \\
\text { (3) }\end{array}$} \\
\hline & $\begin{array}{l}\text { Service provider } \\
\text { (1) }\end{array}$ & $\begin{array}{l}\text { Manufacturer } \\
\text { (2) }\end{array}$ & \\
\hline PAIN & $\begin{array}{l}0.05 \\
(1.43)\end{array}$ & $\begin{array}{l}0.07 * \\
(2.41)\end{array}$ & $\begin{array}{l}0.16 * * \\
(3.34)\end{array}$ \\
\hline $\mathrm{PAIN} \times \mathrm{TECH}$ & - & - & $\begin{array}{l}-0.16^{* * * *} \\
(-3.71)\end{array}$ \\
\hline $\mathrm{PAIN} \times \mathrm{TECH} \times \mathrm{INNO}$ & - & - & $\begin{array}{l}0.06 * * \\
(3.01)\end{array}$ \\
\hline TECH & - & - & $\begin{array}{l}0.13 * * * \\
(3.86)\end{array}$ \\
\hline INNO & $\begin{array}{l}0.05 * * * \\
(5.75)\end{array}$ & $\begin{array}{l}0.05^{*} \\
(2.46)\end{array}$ & $\begin{array}{l}0.05 * * * \\
(6.66)\end{array}$ \\
\hline EXP & $\begin{array}{l}0.01 \\
(0.51)\end{array}$ & $\begin{array}{l}-0.05 \\
(-1.18)\end{array}$ & $\begin{array}{l}0.01 \\
(0.26)\end{array}$ \\
\hline SIZE & $\begin{array}{l}-0.02 \\
(-0.08)\end{array}$ & $\begin{array}{l}-0.54 * * * \\
(-3.64)\end{array}$ & $\begin{array}{l}0.01 \\
(.0 .04)\end{array}$ \\
\hline$(\mathrm{SIZE})^{2}$ & $\begin{array}{l}0.15^{*} \\
(1.08)\end{array}$ & $\begin{array}{l}0.61 * * * \\
(4.44)\end{array}$ & $\begin{array}{l}0.13^{*} \\
(0.94)\end{array}$ \\
\hline PAST & $\begin{array}{l}0.19 * * * \\
(4.08)\end{array}$ & $\begin{array}{l}0.12 * * \\
(2.70)\end{array}$ & $\begin{array}{l}0.19 * * * \\
(4.15)\end{array}$ \\
\hline $\mathrm{R}^{2}$ & $16.9 \%$ & $15.9 \%$ & $17.9 \%$ \\
\hline Obs. & 823 & 738 & 823 \\
\hline \multicolumn{4}{|l|}{ Results of bootstrapping } \\
\hline \multicolumn{4}{|l|}{ PAIN } \\
\hline Mean & 0.19 & 0.18 & 0.61 \\
\hline SD & 0.16 & 0.08 & 0.28 \\
\hline $5 \%$ Perc. & -0.05 & 0.05 & 0.23 \\
\hline $95 \%$ Perc. & 0.46 & 0.30 & 1.07 \\
\hline \multicolumn{4}{|l|}{ PAIN $\times$ TECH [Eq. (5)] } \\
\hline Mean & - & - & -0.81 \\
\hline SD & - & - & -0.50 \\
\hline $5 \%$ Perc. & - & - & -1.56 \\
\hline $95 \%$ Perc. & - & - & -0.31 \\
\hline \multicolumn{4}{|c|}{$\mathrm{PAIN} \times \mathrm{TECH} \times \mathrm{INNO}[$ Eq. $(5)]$} \\
\hline Mean & - & - & 2.22 \\
\hline SD & - & - & 390.35 \\
\hline $5 \%$ Perc. & - & - & -73.38 \\
\hline $95 \%$ Perc. & - & - & 47.50 \\
\hline \multicolumn{4}{|l|}{ INNO } \\
\hline Mean & -0.05 & 1.85 & 0.06 \\
\hline SD & 5.95 & 1.71 & 5.65 \\
\hline $5 \%$ Perc. & -7.46 & 0.45 & -6.90 \\
\hline $95 \%$ Perc. & 3.63 & 5.49 & 3.58 \\
\hline
\end{tabular}

The asterisks represent the levels of significance: $* * *<0.001, * *<0.01, *<0.05$ and ${ }^{\dagger}<0.1$. T-values in parentheses. All regression models include 42 service industry dummies which are not reported here; reference industry (omitted category): NACE 2.0 division 46 "Wholesale trade, except of motor vehicles and motorcycles" 
(mean, SD, the 5th and the 95th percentile) of these sampling distributions (see e.g. Assaf et al. 2011; Barros and Garcia-del-Barrio 2011; Gitto and Mancuso 2012 for the practical application of the bootstrapping procedure.).

The results for the basic model specification are supported by the sampling distributions. The coefficient of PAIN for the service providers changes its sign at the $5 \%$ percentile. Therefore a clear interpretation is impossible. The sampling distribution shows that there is no clear direction of the effect. For the manufacturers the coefficient keeps its sign and therefore has a clear direction of influence as it was found with the parametric regression.

We also control specifically for the INNO term. Again, there is no clear effect for the service providers. Innovativeness has, however, a clear positive effect on the performance of manufacturers. This is supported by the bootstrapping sampling distribution.

As mentioned in Sect. 2, we further differentiate between technology-developing and technology-using service providers by applying Eq. (5) to the data. Column (3) presents the results in this regard.

As for the technology-using service providers (i.e., without the interaction terms), the results suggest a positive and significant relationship between participation intensity and firm performance as hypothesized (Hypothesis 1). As for the technology-developing service providers (i.e., $\left.T E C H_{i}=1\right)$, the second term $\left(P A I N_{i} \times T E C H_{i}\right)$ cancels out the first term $\left(P A I N_{i}\right)$. Thus, participation intensity and firm performance are negatively related as long as the third term $\left(P A I N_{i} \times T E C H_{i} \times I N N O_{i}\right)$ does not affect the relationship (i.e., no or low innovativeness).

However, both variables containing INNO in Eq. (5) have no significant effect on firm performance when considering the results of the bootstrap. Therefore, the second hypothesis cannot be confirmed. As innovativeness is measured by the patent stock, we are able to draw conclusions concerning the protection of intellectual property from these results. The coefficient of $\left(P A I N_{i} \times T E C H_{i} \times\right.$ $\left.I N N O_{i}\right)$ is clearly not significant as indicated by the high standard deviation in the sampling distribution. Therefore, in contrast to our assumption, protection of intellectual property is no clear condition for technology-developing service providers to participate in standardization. Moreover, innovativeness as measured by the single INNO term does again prove not to be significant in the service sector.

For the sake of robustness, the models were additionally estimated with a binary dummy reflecting whether a company participates in standardization or not. Using this proxy instead of the participation intensity based on the number of committee seats within DIN, similar results are found. Moreover, another source of potential endogeneity within the estimation of the firm performance is taken into account. Equation (1) certainly suffers from an omitted- variable bias that might cause endogeneity as can be seen from the regression results in Table 4. Therefore, Eqs. (4) and (5) are additionally estimated using profit (ln $Y_{i}$ ) instead of the estimated firm performance as dependent variable. With this specification very similar results to those of our main regressions are found.

As an additional test, we performed the regression in the basic model specification after replacing PAIN with PART. The results are reported in Table 7. For the estimates of Eq. (4) there is no difference in the results. Concerning the results for Eq. (5), the PART*TECH*INNO interaction term loses its significance in the parametric regression. This is straightforward because PART is dependent on $I N N O$ as shown in Eq. (3). Therefore, no idiosyncratic effect of INNO can be shown using PART. This indicates that it was the right decision to construct the PAIN variable in order to be able to single out specific effects that would otherwise have been lost due to reciprocal dependencies. The bootstrapping results support these findings.

Lastly, we tested several further model specifications. The omission of the PAST variable did not alter the results but lower the $\mathrm{R}^{2}$. Entering INNO or PAIN logarithmically did not yield usable results because in these cases a great amount of observations were lost due to too many zeros and negative values in the sample. We enhanced the models by entering additional interaction terms, namely PAIN*INNO, PAIN*SIZE and PAIN*PAST. Testing their coefficients with the bootstrap method showed that they did not have any explanatory power.

\section{Implications and limitations}

In conclusion, a positive and significant relation between the intensity of participation in standardization and the firm performance is evidenced in manufacturing. This result seems to be robust to several company and industry specific factors as well as to numerous alternative model specifications. All relevant econometric issues such as a sample selections bias and endogeneity due to simultaneity as well as due to an omitted variable bias are accounted for. Thus, we uncovered a first indication for the microeconomic benefit of taking part in formal standardization. This implication rests upon the following trains of thoughts. First, a company always tries to maximize firm performance. Thus, if a company would not experience a benefit from taking part in formal standardization, the company would not get engaged in standardization any longer. Second, based on our results one could argue the other way around insofar as only better performing companies get engaged in formal standardization, which would also explain the positive relation. However, we refuse this reasoning, because it does not seem logical 
Table 7 Estimations of Eqs. (4) and (5) using PART (Step 3)

\begin{tabular}{|c|c|c|c|}
\hline \multirow[t]{2}{*}{$\mathrm{Y}=\mathrm{PERF}$} & \multicolumn{2}{|l|}{ Equation (4) } & \multirow{2}{*}{$\begin{array}{l}\text { Equation (5) } \\
\text { Service provider } \\
\text { (3) }\end{array}$} \\
\hline & $\begin{array}{l}\text { Service provider } \\
\text { (1) }\end{array}$ & $\begin{array}{l}\text { Manufacturer } \\
\text { (2) }\end{array}$ & \\
\hline PART & $\begin{array}{l}0.05 \\
(1.40)\end{array}$ & $\begin{array}{l}0.08^{*} \\
(2.54)\end{array}$ & $\begin{array}{l}0.17 * * \\
(3.33)\end{array}$ \\
\hline $\mathrm{PART} \times \mathrm{TECH}$ & - & - & $\begin{array}{l}-0.16^{* * * *} \\
(-3.55)\end{array}$ \\
\hline PART $\times$ TECH $\times$ INNO & - & $\begin{array}{l}- \\
-\end{array}$ & $\begin{array}{l}0.01 \\
(0.51)\end{array}$ \\
\hline TECH & - & - & $\begin{array}{l}0.14 * * * \\
(3.86)\end{array}$ \\
\hline INNO & $\begin{array}{l}0.05 * * * \\
(5.74)\end{array}$ & $\begin{array}{l}0.04 * \\
(2.45)\end{array}$ & $\begin{array}{l}0.05 * * * \\
(5.97)\end{array}$ \\
\hline EXP & $\begin{array}{l}0.02 \\
(0.56)\end{array}$ & $\begin{array}{l}-0.05 \\
(-1.30)\end{array}$ & $\begin{array}{l}0.01 \\
(0.41)\end{array}$ \\
\hline SIZE & $\begin{array}{l}-0.02 \\
(-0.14)\end{array}$ & $\begin{array}{l}-0.55 * * * \\
(-3.77)\end{array}$ & $\begin{array}{l}-0.02 \\
(-0.13)\end{array}$ \\
\hline$(\mathrm{SIZE})^{2}$ & $\begin{array}{l}0.15 \\
(1.08)\end{array}$ & $\begin{array}{l}0.62 * * * \\
(4.47)\end{array}$ & $\begin{array}{l}0.13 \\
(0.94)\end{array}$ \\
\hline PAST & $\begin{array}{l}0.20 * * * \\
(4.08)\end{array}$ & $\begin{array}{l}0.12 * * \\
(2.70)\end{array}$ & $\begin{array}{l}0.20 * * * \\
(4.15)\end{array}$ \\
\hline $\mathrm{R}^{2}$ & $16.9 \%$ & $16.0 \%$ & $17.7 \%$ \\
\hline Obs. & 823 & 738 & 823 \\
\hline \multicolumn{4}{|l|}{ Results of bootstrapping } \\
\hline \multicolumn{4}{|l|}{ PART } \\
\hline Mean & 0.19 & 0.18 & 0.62 \\
\hline SD & 0.16 & 0.08 & 0.28 \\
\hline $5 \%$ Perc. & -0.05 & 0.06 & 0.25 \\
\hline $95 \%$ Perc. & 0.45 & 0.31 & 1.08 \\
\hline \multicolumn{4}{|l|}{ PART $\times$ TECH $[$ Eq. (5)] } \\
\hline Mean & - & - & -0.85 \\
\hline $\mathrm{SD}$ & - & - & 0.43 \\
\hline $5 \%$ Perc. & - & - & -1.77 \\
\hline $95 \%$ Perc. & - & - & -0.35 \\
\hline \multicolumn{4}{|c|}{$\mathrm{PART} \times \mathrm{TECH} \times \mathrm{INNO}[$ Eq. $(5)]$} \\
\hline Mean & - & - & -2.46 \\
\hline SD & - & - & 25.80 \\
\hline $5 \%$ Perc. & - & - & -51.73 \\
\hline $95 \%$ Perc. & - & - & 37.57 \\
\hline \multicolumn{4}{|l|}{ INNO } \\
\hline Mean & -.40 & 1.54 & -0.67 \\
\hline SD & 5.77 & 1.52 & 6.08 \\
\hline $5 \%$ Perc. & -7.76 & 0.27 & -8.60 \\
\hline $95 \%$ Perc. & 2.45 & 4.63 & 1.83 \\
\hline
\end{tabular}

The asterisks represent the levels of significance: $* * *<0.001, * *<0.01, *<0.05$ and ${ }^{\dagger}<0.1$. All regression models include 42 service industry dummies which are not reported here; reference industry (omitted category): NACE 2.0 division 46 "Wholesale trade, except of motor vehicles and motorcycles" that only better performing companies should get engaged in formal standardization, when participation in formal standardization would not benefit these companies.
Consequently, we encourage managers to exploit the microeconomic benefit of participation within standardization whenever possible. 
As for the standard developing organizations, these results might be used to justify tariffs (necessary to fund the administrative organization of standardization) to the standard setters. Given the already acknowledged positive effects of standards on the demand-side of standardization, an increase in the participation intensity on the supply-side would even further expedite the acceptance of future standards and, therewith, the economic and societal benefits of standards including sustainability issues. Consequently, the paper's findings might contribute to the promotion of the entire standardization system.

With regard to the consideration of the service industries, a clear relation between the engagement in standardization and firm performance is not evidenced. This holds true for both technology-using and technology-developing service providers. In the special case of the latter we find no evidence that supports our second hypothesis. The participation in standardization of technology-developing service providers is not conditional upon the protection of their intellectual property. Service providers seem generally not to be able to profit from the leverage, temporal or network effects of the participation in standardization. This supports our assumption that to date service providers do not use standardization for service technologies but rather use standardization for technologies from the manufacturing sector (Wakke et al. 2012). As standardization is not used in the key field of business, this might explain the missing influence on firm performance.

Based on our results, we see a couple of promising research directions for the future. First of all, the findings only give a first indication for the benefit of participation in standardization. The validation of these findings including more advanced analyses should motivate future research. Especially the causality issue, which is not yet adequately explored in this paper, might be of interest for other scholars. In this regard, there is still the risk that the participation variable picks up omitted effects so that endogeneity might still be prevalent. Moreover, this research does not allow for long-term predictions about a possible benefit of continuously taking part in standardization. Finally, the role of the service sectors in standardization might be further explored. In doing so, other determinants for the participation in standardization than those discussed here can be considered in order to clarify the incentives for service providers.

Acknowledgments The authors appreciate the valuable comments of two reviewers, which helped to improve the quality of the paper substantially. All remaining shortcomings are the sole responsibility of the authors. Paul Wakke received a research grant from the German Standardization Institute DIN e.V. for performing his PhD thesis about service standardization. A preliminary version of this paper is part of his $\mathrm{PhD}$ thesis.
Open Access This article is distributed under the terms of the Creative Commons Attribution 4.0 International License (http://crea tivecommons.org/licenses/by/4.0/), which permits unrestricted use, distribution, and reproduction in any medium, provided you give appropriate credit to the original author(s) and the source, provide a link to the Creative Commons license, and indicate if changes were made.

\section{References}

Antonelli C (1994) Localized technological change and the evolution of standards as economic institutions. Inf Econ Policy 6:195-216

Artz KW, Norman PM, Hatfield DE, Cardinal LB (2010) A Longitudinal study of the impact of R\&D, patents, and product innovation on firm performance. $J$ Prod Innov Manag 27:725-740

Assaf AG, Barros CP, Matousek R (2011) Productivity and efficiency analysis of Shinkin banks: evidence from bootstrap and Bayesian approaches. J Bank Financ 35:331-342

Barros CP, Garcia-del-Barrio P (2011) Productivity drivers and market dynamics in the Spanish first division football league. J Prod Anal 35:5-13

Belderbos R, Carree M, Lokshin B (2004) Cooperative R\&D and firm performance. Res Policy 33:1477-1492

Berger F, Blind K, Thumm N (2012) Filing behaviour regarding essential patents in industry standards. Res Policy 41:216-225

Blind K (2002) Driving forces for standardization in standards development organizations. Appl Econ 34:1985-1998

Blind K (2006a) A taxonomy of standards in the service sector: theoretical discussion and empirical test. The Serv Ind J 26:397-420

Blind K (2006b) Explanatory factors for participation in formal standardisation processes: empirical evidence at firm level. Econ Innov New Technol 15:157-170

Blind K, Jungmittag A (2008) The impact of patents and standards on macroeconomic growth: a panel approach covering four countries and 12 sectors. J Prod Anal 29:51-60

Blind K, Mangelsdorf A (2016) Motives to standardize: empirical evidence from Germany. Technovation. doi:10.1016/j.technova tion.2016.01.001

Briscoe JA, Fawcett SE, Todd RH (2005) The implementation and impact of ISO 9000 among small manufacturing enterprises. J Small Bus Manag 43:309-330

Cainelli G, Evangelista R, Savona M (2006) Innovation and economic performance in services: a firm-level analysis. Camb J Econ 30:435-458

Cebr (2015) The economic contribution of standards to the UK economy. Research funded by the Department for Business Innovation \& Skills. BSI, London

Chesbrough H (2003) Open Innovation. Havard University Press, Cambrigde

Chiesa V, Toletti G (2003) Standard-setting strategies in the multimedia sector. Int J Innov Manag 7:281-308

Cohen J, Cohen P, West SG, Aiken LS (2003) Applied Multiple Regression/Correlation Analysis for the Behavioral Sciences. Erlbaum, Mahwah

Corbett CJ, Montes-Sancho MJ, Kirsch DA (2005) The financial impact of ISO 9000 certification in the United States: an empirical analysis. Manag Sci 51:1046-1059

Crépon B, Duguet E, Mairesse J (1998) Research, innovation and productivity: an econometric analysis at the firm level. Econ Innov New Technol 7:115-158

Czarnitzki D, Kraft K (2010) On the profitability of innovative assets. Appl Econ 42:1941-1953 
David PA, Greenstein S (1990) The economics of compatibility standards: an introduction to recent research. Econ Innov New Technol 1:3-41

Dhawan R (2001) Firm size and productivity differential: theory and evidence from a panel of US firms. J Econ Behav Organ 44:269-293

Droege H, Hildebrand D (2009) Innovation in services: present findings, and future pathways. J Serv Manag 20:131-155

DTI (2005) The empirical economics of standards. DTI Economics Paper 12, London: Department of Trade and Industry, www.bis. gov.uk/files/file9655.pdf

Duysters G, Lokshin B (2011) Determinants of alliance portfolio complexity and its effect on innovative performance of companies. J Prod Innov Manag 28:570-585

Dyer JH, Singh H (1998) The relational view: cooperative strategy and sources of interorganizational competitive advantage. Acad Manag Rev 23:660-679

Fernández E, Montes JM, Vázquez CJ (2000) Typology and strategic analysis of intangible resources. Technovation 20:81-92

Friedman LW, Friedman HH (1995) Analyzing simulation output using the bootstrap method. Simul 64:95-100

Gitto S, Mancuso P (2012) Bootstrapping the Malmquist indexes for Italian airports. Int J Prod Econ 135:403-411

Glueckler J, Hammer I (2011) A pragmatic service typology: capturing the distinctive dynamics of services in time and space. The Serv Ind J 31:941-957

Gotsch M, Hipp C (2012) Measurement of innovation activities in the knowledge intensive services industry: A trademark approach. The Serv Ind J 32:2167-2184

Griliches Z (1995) R\&D and Productivity: Econometric Results and Measurement Issues. In: Stoneman P (ed) Handbook of the Economics of Innovation and Technological Change. Blackwell Publishers, Oxford

Hall BH, Mairesse J, Mohnen P (2009) Measuring the returns to R\&D. NBER Working Paper 15622

Hipp C, Grupp H (2005) Innovation in the service sector: the demand for service-specific innovation measurement concepts and typologies. Res Policy 34:517-535

Hytönen, H, Jarimo T, Salo A, Yli-Juuti E (2012) Markets for standardized technologies: patent licensing with principle of proportionality. Technovation 32:523-535

Jungmittag A, Blind K, Grupp H (1999) Innovation, standardisation and the long-term production function. A cointegration analysis for Germany 1960-96. Zeitschrift fuer Wirtschafts- und Sozialwissenschaften (ZWS) 119:205-222

Kneller R, Pisu M (2010) The returns to exporting: evidence from UK firms. Can J Econ 43:494-519

Koellinger P (2008) The relationship between technology, innovation, and firm performance - Empirical evidence from e-business in Europe. Res Policy 37:1317-1328

Kumbhakar SC, Ortega-Argilés R, Potters L, Vivarelli M, Voigt P (2012) Corporate R\&D and firm efficiency: evidence from Europe's top R\&D investors. J Prod Anal 37:125-140

Laursen K, Salter A (2006) Open for innovation: the role of openness in explaining innovation performance among U.K. manufacturing firms. Strateg Manag J 27:131-150

Lecraw DJ (1984) Some economic effects of standards. Appl Econ 16:507-522

Leiponen A, Helfat CE (2010) Innovation objectives, knowledge sources, and the benefit of breadth. Strateg Manag J 31:224-236

Love JH, Roper S (1999) The determinants of innovation: R\&D, technology transfer and networking effects. Rev Ind Organ $15: 43-64$
Manez-Castillejo JA, Rochina-Barrachina ME, Sanchis-Llopis JA (2010) Does firm size affect self-selection and learning-byexporting? World Econ 33:315-346

Miozzo M, Soete L (2001) Internationalization of services: a technological perspective. Technol Forecast Soc Change 67:159-185

Morrison CJ (1999) Cost Structure and the Measurement of Economic Performance. Kluwer Academic Publishers, Norwell

Olley GS, Pakes A (1996) The Dynamics of Productivity in the Telecommunications Equipment Industry. Econometrica 64: 1263-1297

Pekovic S, Galia F (2009) From quality to innovation: evidence from two French employer surveys. Technovation 29:829-842

Pohlmann T, Neuhäusler P, Blind K (2015) Standard essential patents to boost financial returns. R\&D Management. doi:10.1111/radm. 12137

Rysman M, Simcoe T (2008) Patents and the Performance of Voluntary Standard-Setting Organizations. Manag Sci 54:1920-2934

Salop SC, Scheffman DT (1983) Raising rivals costs. Am Econ Rev 73:267-271

Salop SC, Scheffman DT (1987) Cost-raising strategies. J Ind Econ 36:19-34

Schmoch U, Gauch S (2009) Service marks as indicators for innovation in knowledge-based services. Res Eval 18:323-335

Schumpeter JA (1934) The theory of economic development. Harvard University Press, Cambridge

Simar L, Wilson PW (1999) Estimating and Bootstrapping Malmquist Indices. Eur J Oper Res 115:459-471

Simcoe T (2012) Standard Setting Committees: consensus Governance for Shared Technology Platforms. Am Econ Rev 102:305-336

Swann GMP (2010) The economics of standardization: An update. Report for the UK Department of Business, Innovation and Skills (BIS)

Tien SW, Chung YC, Tsai CH (2005) An empirical study on the correlation between environmental design implementation and business competitive advantages in Taiwan's industries. Technovation 25:783-794

Tsai KH (2005) R\&D productivity and firm size: a nonlinear examination. Technovation 25:795-803

van de Wiele P (2010) The impact of training participation and training costs on firm productivity in Belgium. Int J Hum Resour Manag 21:582-599

Vence X, Trigo A (2009) Diversity of innovation patterns in services. Serv Ind J 29:1635-1657

von Hippel E (1988) The sources of innovation. Oxford University Press, New York

Wakke P, Blind K, Vries H de (2012) The relationship between innovation in services and standardization: Empirical evidence of service providers' involvement in standardization. Working paper available at http://papers.ssrn.com/sol3/papers.cfm?ab stract_id=2045484

Wakke P, Blind K, Vries H de (2015) Driving factors for service providers to participate in standardization: insights from the Netherlands. Ind Innov 22:299-320

Weiss MBH, Sirbu M (1990) Technological choice in voluntary standards committees: an empirical analysis. Econ Innov New Technol 1:111-133

Zutshi A, Sohal A (2004) Environmental management system adoption by Australasian organisations: part 1: reasons, benefits and impediments. Technovation 24:335-357 